\title{
POSSIBLE MECHANISM OF DISINTEGRIN/LIKE DOMAIN IN MESENCHYMAL STEM CELLS HOMING IN MICE LIVER INJURY MODEL
}

\author{
Amal Said Darwish1, Walid Said Zaki1, Ayman Ragaa Basheer1, \\ Hanaa El-Tayeb Nasser1, Mohamed Farid El-Asmar1
}

1DEPARTEMENT OF MEDICAL BIOCHEMISTRY AND

MOLECULAR BIOLOGY, FACULTY OF MEDICINE, AINSHAMS UNIVERSITY, CAIRO, EGYPT.

Received 4/6/2017 - Accepted 10/9/2017

\begin{abstract}
Liver disease is one of the major health problems in many countries. Mesenchymal Stem cells have opened a new approach to deal with liver fibrosis. Improvement of bone marrow derived mesenchymal stem cellshoming after systemic injection of disintegrin/like domain purified from Egyptian horned Cerastes cerastes crude venomwhichwas shown byprevious study. This work was designed to investigate the possible mechanism of disintegrin/like domainin mesenchymal stem cells homing to fibrotic liver of $\mathrm{CCl}_{4}$ treated mice. Quantitative gene expression was performed for stromal cell-derived factor- $1 \alpha$ to study homing of bone marrow derived mesenchymal stem cells, transforming growth factor beta 1 to study bone marrow derived mesenchymal stem cellshoming and regeneration of liver cells and hepatocyte growth factor to study regeneration of liver cells in $\mathrm{CCl}_{4}$ induced liver injury in white albino mice. It was found that disintegrin/like domaincould increase homing ofbone marrow derived mesenchymal stem cells as showed by the significant increase in liver stromal cell-derived factor $-1 \alpha$ gene expression, transforming growth factor beta 1 as well as hepatocyte growth factor genes expression compared to the non disintegrin/like domaintreated $\mathrm{CCl}_{4}$ group.
\end{abstract}

Keywords: BM-MSCs; $\mathrm{CCl}_{4}$; HGF; SDF- $1 \alpha$; TGF- $\beta 1$.

*Correspondence Author(e mail: saso_darweesh@yahoo.com) 
This manuscript was adapted from a thesis submitted to Faculty of Medicine, Ain Shams University for PHD degree in medical biochemistry and molecular biology by Amal Darwish.

\section{INTRODUCTION}

Mesenchymal stromal cells (MSCs) are non-haematopoietic cells that were first obtained from the bone marrow(Friedenstein et al., 1974).There is great interest in using these cells in therapy ofwide variety of clinical problems(Wang et al., 2015 and De Becker A, Van Riet,2015).Mesenchymal stromal cells have immunomodulatory effect, multipotentcapacity and tend to migrate to sites of tissue injury(Chapel et al., 2003 andNasef et al., 2009). In addition, MSCs can suppress inflammatory responses, reduce hepatocyte apoptosis, increase hepatocyte regeneration, and rescue liver fibrosis(Eom et al., 2015).Homing isa major problem in the field of cell-based therapy which means the ability of cells to migrate into the site of injury. Homing is a multistep process that includes cell attachment and rolling in the vessel lumen, adhesion and extravasation across the vascular endothelium and migration through the tissue stroma(Kholodenko et al., 2013).

Many potential factors are involved in stem cells migration and homing into the injured liver have been characterized, such as stromal cell-derived factor- $1 \alpha$ (SDF-1 $\alpha /$ CXCR4) axis, lytic enzymes as matrix metalloproteinase (MMPs), hypoxia induced factor -1(HIF-1), hepatocyte growth factor (HGF),inflammatory cytokines such as (transforming growth factor beta 1 (TGF- $\beta 1$ ), interleukin-1 $\beta$ (IL-1 $\beta$ ) and tumor necrosis factor- $\alpha($ TNF- $\alpha)($ Sohni and Verfaillie, 2013).

Disintegrins are small cysteine-rich non-enzymatic proteins that are created by the proteolysis of larger precursor of snake venom metalloproteinase(Takeda et al., 2012). They have been found to inhibit platelet aggregation, angiogenesis, metastasis and tumor growth(Amiryan, 2011). The value of disintegrin/like domainobtained from Egyptian horned Cerastes cerastes crude venom as hepatoprotective(Zaki et al., 2011)and potential stimulator of mesenchymal stem cells homing was reportedin albino mice(Abd EL-Wahab et al., 2014).

Stromal cell-derived factor- $1 \alpha$ is constitutively expressed in healthy liver. Its expression increases following acute or chronic liver 
injury.Stromal cell-derived factor- $1 \alpha$ (SDF-1 $\alpha)$ is able to activate two chemokine receptors with various downstream signaling pathways, $\mathrm{C}-\mathrm{X}-$ $\mathrm{C}$ chemokine receptor type 4 (CXCR4) and $\mathrm{C}-\mathrm{X}-\mathrm{C}$ chemokine receptor type 7 (CXCR7).C $-\mathrm{X}-\mathrm{C}$ chemokine receptor type7 is much more expressed inliver sinusoidal endothelial cells (LSEC), while hepatic stellate cells (HSC), mesenchymal stem cells, and tumor cells mainly respond by CXCR4 expression(Liepelt and Tacke, 2016).

Hepatocyte growth factorhas pleiotropic effects on liver cells, influencing cell proliferation, apoptosis, differentiation, motility, invasion and angiogenesis(Weiskirchen, 2015). The positive role of HGF in facilitating the differentiation of stem cells has been recognized as a rational approach to improve the efficacy of MSC transplantation(Hahn et al., 2008).

Transforming growth factor beta 1 is a multifunctional cytokine(Thenappan et al., 2011). Transforming growth factor beta 1 is hypothesized to serve as the vital link among liver regeneration, chronic injury, cirrhosis, and hepatocellular carcinoma(Thenappan et al.,2010).It is hypothesized that TGF- $\beta 1$ may mediate SDF- $1 \alpha / \mathrm{CXCR} 4$ axis-induced MSCs homing(Si et al., 2015).

This study investigated the possible mechanism by which disintegrin /like domain could enhance the homing of labeled bone marrow mesenchymal stem cells to $\mathrm{CCl}_{4}$ induced liver injury model in white albino mice.

\section{MATERIALS AND METHODS}

\section{Purification and isolation of disintegrin/ like domain:}

Disintegrin /like domain was purified from Egyptian horned Cerastes cerastes crude snake venom(Zaki et al., 2011)

Preparation ofbone marrow derived mesenchymal stem cells:

Freshly isolated and labeled bone marrow derived mesenchymal stem cells (BM-MSCs)with PKH26 fluorescent dyewere obtained as injectable preparations $\left(2 \times 10^{6}\right.$ cells $\left./ \mathrm{ml}\right)$ from Unit of Biochemistry and Molecular Biology (UBMB)-Cairo University.

\section{Experimental design:}

Male white albino mice of average weight (25-30 g/mouse)were kept in wire cages at animal house under standard conditions. Food and water were available ad-libitum (fed freely with the quantity and frequency of consumption of choice of animals). They were divided randomly into 5groups, each of 8 animals(Abd EL-Wahab et al., 
2014): Group 1 (control): Injected intra-peritoneally (i.p.) with normal saline once weekly for 3 weeks in a dose of $0.8 \mathrm{ml} / \mathrm{kg}$ body weight then sacrificed one week later; Group 2: Injected (i.p.)with $\mathrm{CCl}_{4} 0.8$ $\mathrm{ml}(95 \%) / \mathrm{kg}$ body weight once weekly for 3 successive weeksthen sacrificed one week later; Group 3: Injected (i.p.)with $\mathrm{CCl}_{4} 0.8 \mathrm{ml}$ $(95 \%) / \mathrm{kg}$ once weekly for 3 successive weeks followed one week later by (i.p.)injection of disintegrin/likedomain $0.3 \mathrm{mg} / \mathrm{kg}$ once weekly for 2 successive weeks then sacrificed one week later; Group 4: Injected (i.p.)with $\mathrm{CCl}_{4} 0.8 \mathrm{ml} / \mathrm{kg}$ once weekly for 3 successive weeks followed one week later by intra-venous injection of $0.5 \mathrm{ml}$ labeled BM- MSCs $\left(2 \times 10^{6}\right.$ cells $/ \mathrm{ml}$ once) (cells were injected intra-venous into mice tail vein)then sacrificed3 weeks later; Group 5: Injected (i.p.)with $\mathrm{CCl}_{4} 0.8 \mathrm{ml}(95 \%) / \mathrm{kg}$ once weekly for 3 successive weeks followed one week later by intra-venous injection of $0.5 \mathrm{ml}$ labeled $\mathrm{BM}-\mathrm{MSCs}\left(2 \times 10^{6}\right.$ cells $\left./ \mathrm{ml}\right)$ (cells were injected intra-venous into mice tail vein) and (i.p.)injection of disintegrin/like domain $0.3 \mathrm{mg} / \mathrm{kg}$ then sacrificed 3 week later.This work was approved by research ethics committee, faculty of medicine- Ain shams university (NO. FWA 000017585).

All groupswere anaesthetized by ether and blood samples were obtainedby periorbital route(Joanna et al., 2015)andsacrificed to obtain the liver tissues.Hepatic specimens were treated for Real Time PCR and histo-pathological studies.

\section{Biochemical assays:}

Serum alanine aminotransferase (ALT), aspartate aminotransferase (AST) and albumin levels were measured with a biochemical analyzer (Roche Integra 800, Holliston, United States)(Bergmeyer et al., 1985).

RNA isolation and quantitative real-time RT-PCR:

RNA extraction from liver tissue samples was performed(Otto et al., 1998). Total RNA was isolated using the SV(spin or vacuum) Total RNA Isolation system (Promega, Madison, WI, USA);reverse transcription (QuantiTect®Reverse Transcription kit) manufactured by (QIAGEN, Germany);real-time quantitative PCR(Livak and Schmittgen, 2002) (Quantitect SYBR green PCR kit; Qiagen) on a Rotor-Gene ${ }^{\circledR}$ cyclersReal-Time PCR detection system. Specific PCR primers were obtained from gene bank database and provided by (Invitrogen analysis company)(table1). 
Table 1: Gene primers used for detection

\begin{tabular}{|r|r|r|}
\hline \multicolumn{1}{|c|}{ Gene } & \multicolumn{1}{|c|}{ Sense } & \multicolumn{1}{c|}{ Antisense } \\
\hline HGF & AGCTCAGAACCGACCGGCTTGCAACAGGAT & TTACCAATGATGCAATTTCTAATATAGTCT \\
\hline TGF- $\beta 1$ & CTTCAGCTCCACAGAGAAGAACTGC & CACGATCATGTTGGACAACTGCTCC \\
\hline SDF-1 $\alpha$ & CGCCAGAGCCAACGTCAAGC & TTCGGGTCAATGCACACTTG \\
\hline GAPDH & TCAACAGCAACTCCCACTCTTCCA & ACCCTGTTGCTGTAGCCGTATTCA \\
\hline
\end{tabular}

\section{Examination of liver histo-pathology:}

Liver tissue samples of each group were immediately fixed in $20 \%$ formaline then kept in paraffin, staining of thin transverse sections with haemtoxylin and eosin stain was performed(Achliya et al., 2003). Unstained liver tissue sections from the 4th and 5th groups were examined with a fluorescence microscope to detect the BM- MSCs stained with PKH26 (Abdel Aziz et al., 2011).The prepared and stained sections were examined by a histopathologist as indicated in acknowledgement.

\section{Statistical analysis:}

Data of biochemical assays were expressed as mean \pm SD. Significant differences were determined by using one wayanalysis of variance(ANOVA) for multiple comparisons using SPSS 20.0 computer Software. Results were considered significant at $\mathrm{p} \leq 0.05$. The results of Real Time PCRwere expressed as median and range. Their distribution between different groups was tested using Kruskal_wallis nonparametric test. Pairwise comparisons were done using Mann-Whitney test with Bonferroni adjustment of obtained $\mathrm{p}$ value.P value $\leq 0.05$ was considered statistically significant $(Z$ willinger and Kokoska, 2000).

\section{RESULTS}

PKH26 fluorescent dyelabeledMSCs were observed in the liver tissues obtained from the group injected with $\mathrm{MSCs}$ after $\mathrm{CCl}_{4}$ (group 4) (figure 1) and the group injected with MSCs and disintegrin/ like domain after $\mathrm{CCl}_{4}$ (group5) (figure 2) 

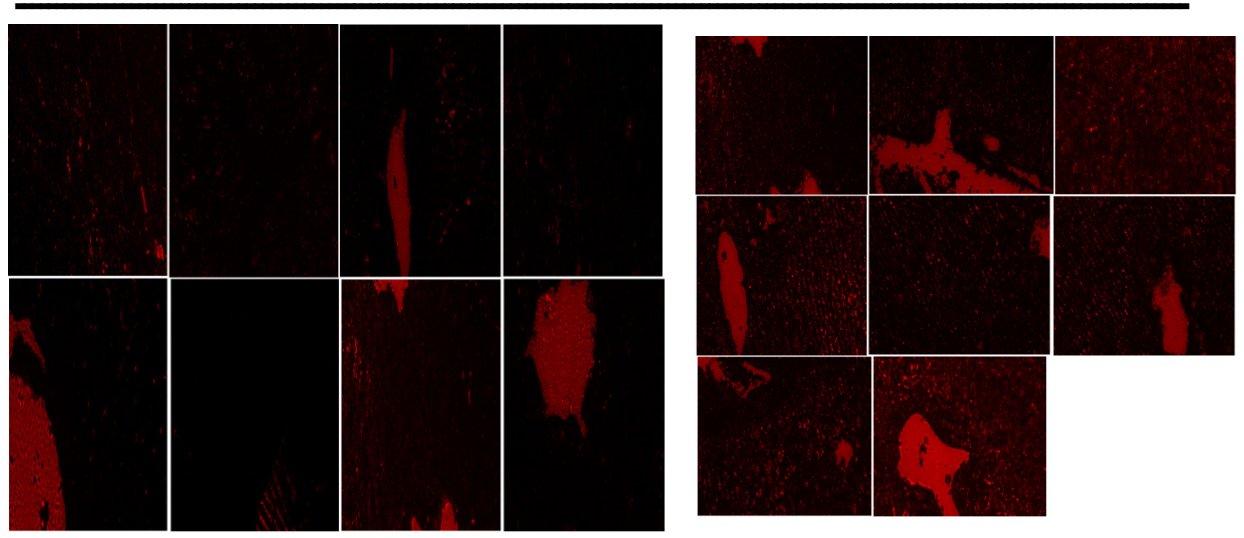

Figure (1): the PKH26 labeled bone marrow derived mesenchymal stem cells appeared as red auto-fluorescence after intravenous injection into mice. The cells showed sporadic distribution in the field confirming that these cells were seeded into the injured liver tissue.

Figure (2): the PKH26 labeled bone marrow derived mesenchymal stem cells appeared as relative stronger and more diffuse red auto-fluorescence after intravenous injection into mice as compared to (figure 1) suggesting that these cells were more seeded into the liver tissue.

Serum ALT and AST levels (U/L) were significantly increased in $\mathrm{CCl}_{4}$ treated animals as compared to that in the control group (P $\leq \mathbf{0 . 0 1})$. Serum albumin levels (g/dl) were significantly decreased in animals injected with $\mathrm{CCl}_{4}$ as compared to the control group $(\mathrm{p} \leq 0.01)$ indicating presence of liver damage (table 2).

Table 2:Comparison between group 1 and group 2 as regard serum AST, ALT and albumin levels

\begin{tabular}{|c|c|c|c|c|}
\hline Groups & No & ALT(U/L) & AST(U/L) & Albumin(g/dl) \\
\hline Group1 & 8 & $55.3 \pm 20.4$ & $92.7 \pm 13.3$ & $3.9 \pm 0.3$ \\
\hline Group2 & 8 & $\begin{array}{c}131.3 \pm 52.7 \\
* *\end{array}$ & $\begin{array}{c}367.3 \pm 96.5 \\
* *\end{array}$ & $2.4 \pm 1.1^{* *}$ \\
\hline
\end{tabular}

The results were expressed as mean \pm standard deviation (SD). ${ }^{*}$ "Significant at $\mathrm{p} \leq 0.01$; Group 1: control; Group 2: Injected with $\mathrm{CCl}_{4}$

SerumALT and AST levels were significantly lower in mice injected with disintegrin/ like domain or labeled BM-MSCs or both after $\mathrm{CCl}_{4}$ injection, compared to that injected with $\mathrm{CCl}_{4}$ alone $(\mathrm{p} \leq 0.01)$. 
Serum albumin levels were significantly increased in mice injected with disintegrin/ like domain or labeled BM-MSCs or both after $\mathrm{CCl}_{4}$, compared to mice injected with $\mathrm{CCl}_{4}$ alone $(\mathrm{p} \leq 0.05)($ table 3$)$.

Table 3: Comparison between group 2 and other groups as regard serum ALT, AST and albumin levels

\begin{tabular}{|c|c|c|c|c|}
\hline Groups & no & ALT (U/L) & AST (U/L) & Albumin (g/dl) \\
\hline Group 2 & 8 & $131.3 \pm 52.7$ & $367.3 \pm 96.5$ & $2.4 \pm 1.1$ \\
\hline Group 3 & 8 & ${ }^{* *} 63.2 \pm 19.1$ & ${ }^{* *} 178.3 \pm 56.1$ & ${ }^{* *} 3.3 \pm 0.3$ \\
\hline Group 4 & 8 & ${ }^{* *} 60.6 \pm 19.8$ & $\begin{array}{c}187.2 \pm 70.2 \\
{ }^{* * *}\end{array}$ & ${ }^{*} 3.1 \pm 0.1$ \\
\hline Group 5 & 8 & ${ }^{* *} 62.1 \pm 25.1$ & ${ }^{* *} 163.5 \pm 55.2$ & ${ }^{*} 3.0 \pm 0.1$ \\
\hline
\end{tabular}

The results were expressed as mean \pm standard deviation (SD). Significant at ${ }^{*} \mathrm{p} \leq 0.05$ and ${ }^{*} \mathrm{p} \leq 0.01$; Group 2: Injected with $\mathrm{CCl}_{4}$; Group 3: Injected with $\mathrm{CCl}_{4}$ followed by disintegrin/like domain; Group 4: Injected with $\mathrm{CCl}_{4}$ followed by BM- MSCs; Group 5: Injected with $\mathrm{CCl}_{4}$ followed by BMMSCs and disintegrin/like domain.Concerning hepatocyte growth factor (HGF) gene expression; miceinjected with $\mathrm{CCl}_{4}, \mathrm{BM}-\mathrm{MSCs}$ and disintegrin/like domainshowed the highest relative quantitative(RQ) values.Stromal cell-derived factor- $1 \alpha($ SDF- $1 \alpha)$ gene expression; miceinjected with $\mathrm{CCl}_{4}, \mathrm{BM}$ - MSCs and disintegrin/like domainshowed the highest RQ values.Transforming growth factor beta 1(TGF- $\beta 1$ )gene expression;miceinjected with $\mathrm{CCl}_{4}$ and disintegrin/like domainwere showed the highest RQ values (table 4).

Table (4): Relative quantification analysisas regard HGF,SDF-1 $\alpha$ andTGF- $\beta 1$.

\begin{tabular}{|c|c|c|c|c|c|c|}
\hline \multirow[t]{2}{*}{ Groups } & \multicolumn{2}{|c|}{$\begin{array}{l}\text { Hepatocyte } \\
\text { growth factor }\end{array}$} & \multicolumn{2}{|c|}{$\begin{array}{l}\text { Stromal cell- } \\
\text { derived factor- } \\
1 \alpha \\
\end{array}$} & \multicolumn{2}{|c|}{$\begin{array}{c}\text { Transforming } \\
\text { growth factor beta } \\
1 \\
\end{array}$} \\
\hline & Median & Range & Median & Range & Median & Range \\
\hline 1 (saline) & 0.35 & $\begin{array}{r}0.125- \\
2.35\end{array}$ & 1 & $\begin{array}{r}0.75- \\
1.4\end{array}$ & 2.35 & $\begin{array}{r}0.225- \\
6.825 \\
\end{array}$ \\
\hline $2\left(\mathrm{CCl}_{4}\right)$ & 5.5 & $\begin{array}{r}1.1- \\
5.775 \\
\end{array}$ & 2.8 & $1.4-4.1$ & 53.6 & $\begin{array}{r}45.175- \\
59.85\end{array}$ \\
\hline $3\left(\mathrm{CCl}_{4}+\right.$ disintegrin $)$ & 70.1 & $\begin{array}{l}61.975- \\
139.575\end{array}$ & 12.2 & $\begin{array}{r}1.975- \\
17.25\end{array}$ & 1675.45 & $\begin{array}{r}1142.425- \\
2012.525\end{array}$ \\
\hline $4\left(\mathrm{CCl}_{4}+\mathrm{MSCs}\right)$ & 5.5 & $\begin{array}{l}1.35- \\
7.925\end{array}$ & 7.6 & $\begin{array}{l}2.125- \\
13.175\end{array}$ & 2.8 & $\begin{array}{r}0.925- \\
5.975 \\
\end{array}$ \\
\hline $\begin{array}{r}5\left(\mathrm{CCl}_{4}+\mathrm{MSCs}+\right. \\
\text { disintegrin }) \\
\end{array}$ & 190.35 & $\begin{array}{r}62.275- \\
317.275 \\
\end{array}$ & 25.4 & $\begin{array}{r}18.175- \\
28.5 \\
\end{array}$ & 3.85 & $3.5-5.275$ \\
\hline
\end{tabular}


Miceinjected with $\mathrm{CCl}_{4}$ and disintegrin/like domainand miceinjected with $\mathrm{CCl}_{4}, \mathrm{BM}-\mathrm{MSCs}$ and disintegrin/like domainshowed significantly increased expression $(\mathrm{p} \leq 0.01)$ of HGF gene compared tomice injected with $\mathrm{CCl}_{4}$. Whereas, mice injected with $\mathrm{CCl}_{4}, \mathrm{BM}-$ MSCs and disintegrin/like domain showed significantly increased expression $(\mathrm{p} \leq 0.01)$ of HGF gene compared to mice injected with $\mathrm{CCl}_{4}$ and BM-MSCs. Also,miceinjected with $\mathrm{CCl}_{4}, \mathrm{BM}-\mathrm{MSCs}$ and disintegrin/like domainshowed significantly increased expression $(\mathrm{p} \leq 0.01)$ of SDF-1 $\alpha$ gene compared tomice injected with $\mathrm{CCl}_{4}$. While, miceinjected with $\mathrm{CCl}_{4}, \quad \mathrm{BM}-\mathrm{MSCs}$ and disintegrin/like domainshowed significantly increased expression $(\mathrm{p} \leq 0.01)$ of SDF- $1 \alpha$ gene compared to miceinjected with $\mathrm{CCl}_{4}$ and BM- MSCs.

Miceinjected with $\mathrm{CCl}_{4}$ and disintegrin/like domainshowed significantly increased expression $(\mathrm{p} \leq 0.01)$ of $\mathrm{TGF}-\beta 1$ gene compared to miceinjected with $\mathrm{CCl}_{4}$. While,miceinjected with $\mathrm{CCl}_{4}$ and $\mathrm{BM}$ MSCs andmiceinjected with BM- MSCs and disintegrin/like domainafter $\mathrm{CCl}_{4}$ treatment showed significantly decreased expression $(\mathrm{p} \leq 0.05)$ compared to miceinjected with $\mathrm{CCl}_{4}$ and $(\mathrm{p} \leq 0.01)$ compared to miceinjected withCCl $\mathrm{Cl}_{4}$ and disintegrin/like domain (table 5).

Table 5: Pairwise comparison between 5 groups as regard HGF,SDF- $1 \alpha$ andTGF- $\beta 1$.

\begin{tabular}{|c|c|c|c|c|}
\hline \multirow{2}{*}{ Group } & \multirow{2}{*}{ Versus Groups } & \multicolumn{3}{|c|}{$p$ value } \\
\hline & & HGF & $\begin{array}{c}\text { SDF- } \\
1 \alpha\end{array}$ & $\begin{array}{c}\text { TGF- } \\
\boldsymbol{\beta 1}\end{array}$ \\
\hline \multirow{4}{*}{1 (Saline) } & $\mathrm{CCl}_{4}$ & 0.52 & 0.09 & ${ }^{*} 0.03$ \\
\hline & $\mathrm{CCl}_{4}+$ disintegrin & $\begin{aligned} 0.01 \\
* * *\end{aligned}$ & 0.16 & $* * 0.01$ \\
\hline & $\mathrm{CCl}_{4}+\mathrm{MSCs}$ & 0.18 & 0.11 & 7.13 \\
\hline & $\mathrm{CCl}_{4}+\mathrm{MSCs}+$ disintegrin & 0.01 & $* * 0.01$ & 6.74 \\
\hline \multirow{3}{*}{$2\left(\mathrm{CCl}_{4}\right)$} & $\mathrm{CCl}_{4}+$ disintegrin & ${ }^{* * *} 0.01$ & 1.02 & ****0.01 \\
\hline & $\mathrm{CCl}_{4}+\mathrm{MSCs}$ & 4.01 & 1.41 & ${ }^{*} 0.02$ \\
\hline & $\mathrm{CCl}_{4}+\mathrm{MSCs}+$ disintegrin & ${ }^{* * *} 0.01$ & ***0.01 & ${ }^{*} 0.02$ \\
\hline \multirow{2}{*}{$3\left(\mathrm{CCl}_{4}+\right.$ disintegrin $)$} & $\mathrm{CCl}_{4}+\mathrm{MSCs}$ & $* * 0.01$ & 3.45 & $* * 0.01$ \\
\hline & $\mathrm{CCl}_{4}+\mathrm{MSCs}+$ disintegrin & 1.72 & 0.06 & ***0.01 \\
\hline $4\left(\mathrm{CCl}_{4}+\mathrm{MSCs}\right)$ & $\mathrm{CCl}_{4}+\mathrm{MSCs}+$ disintegrin & $* * 0.01$ & $* * 0.01$ & 5.28 \\
\hline
\end{tabular}


Abd EL-Wahab et al., (2014)observed thatdisintegrin/ like domain can increase homing of BM-MSCslabelled with the PKH26 into injured liver tissues of $\mathrm{CCl}_{4}$ treated mice. The current studyconfirmed the same results as shown by difference between mice injected with disintegrin/ like domain and MSCs and mice injected with MSCs in PKH26 fluorescence dye studies.

In the presentwork, AST and ALT serum levels (U/L) were significantly increased in animals injected with $\mathrm{CCl}_{4}$ as compared to the control group. The results were consistent withAbd El-Wahab et al. (2014)and Lee et al. (2017)studies, indicating hepatic damage. While, the present study showed significant decrease of serum ALT and AST levels in animals injected with MSCs and/ or disintegrin/ like domain after $\mathrm{CCl}_{4}$ injection as compared to animals injected with $\mathrm{CCl}_{4}$ alone. This goes with,Abd EL-Wahab et al. (2014).

Data of present study showed also that serum albumin levels $(\mathrm{g} / \mathrm{dl})$ were significantly decreased in animals injected with $\mathrm{CCl}_{4}$ compared to control group. The results were consistent with Ahmed et al. (2014)and Sahreen et al. (2015). There was significant improvement in serum albumin levels in animals injected with disintegrin/ like domain or labeled BM-MSCsor bothafter intra-peritoneal injection with $\mathrm{CCl}_{4}$ compared to animals injected with $\mathrm{CCl}_{4}$ alone indicating improvement of hepatocytes to produce albumin.This goes withZhao et al. (2012) and Ahmed et al. (2014)who injected BM-MSCs (for 4 weeks) in animals treated with $\mathrm{CCl}_{4}$.

In contrast, Abd EL-Wahab et al. (2014)reported no significant improvement in serum albumin levels in animals injected with disintegrin/ like domain or labeled BM-MSCs or both after injection with $\mathrm{CCl}_{4}$ compared to animals injected with $\mathrm{CCl}_{4}$ alone. This difference might be due to the difference in the time provided foreach experiment; in present report 3 weeks were allowed to restore liver function to synthesize albumin but in Abd EL-Wahab et al. (2014)study only 1week was allowed then animals were sacrieficed.As regard quantitative gene expression analysis, the current work showed highest significant expression of SDF-1 $\alpha$ levels in mice injected with $\mathrm{CCL}_{4}$, disintegrin/like domain andMSCscompared to control group,mice injected withCCL $\mathrm{CL}_{4}$ and mice injected with $\mathrm{CCL}_{4}$ and MSCs. 
Liepelt and Tacke, (2016)demonstrated that SDF-1 $\alpha$ contributed to modulate liver injury and subsequent tissue regeneration by SDF-1 $\alpha-$ CXCR7 interactions. Ling et al. (2016) showed the role of SDF-1 $\alpha$ /CXCR4 axis in the recruitment of BM-MSCs into thioacetamide (TAA) induced liver injury.They revealed that SDF-1 $\alpha$ can induce BM-MSCs migration which is blocked by neutralizing anti-CXCR4 antibody in vitro and in vivo, SDF-1 $\alpha$ /CXCR4 axis is involved in BM-MSCs migration into the injured liver in vitro and in vivo.

The current study revealed that SDF- $1 \alpha$ might regulate the recruitment of MSCs in fibrotic liver and showed the probable synergistic effect ofdisintegrin/like domain in increasing the homing of MSCs as shown byfluorescence microscope.

The present study showed also significant increase of TGF- $\beta 1$ gene expression in mice injected with $\mathrm{CCL}_{4}$ compared to control group.Consistent with current resultsMotawi et al. (2014)and Park et al. (2015).Fan et al. (2013) verified that TGF- $\beta 1$ is a pro-fibrogenic cytokines in hepatic fibrosis. Linard et al. (2013), Shao et al. (2014)andParket al. (2015) reported that MSCs have potential antifibrotic effect through down-regulation of TGF- $\beta 1$ expression.

In present study the expression of TGF- $\beta 1$ was significantly decreased in mice injected with $\mathrm{CCl}_{4}$ and with MSCs and mice injected with $\mathrm{CCL}_{4}$, disintegrin/ like domain and MSCs. But there is significant increase of TGF- $\beta 1$ gene expression in mice injected with $\mathrm{CCL}_{4}$ and disintegrin like/domain compared to control and mice injected with $\mathrm{CCL}_{4}$. This suggests that disintegrin like/domain might increase MSCs homing through TGF- $\beta 1$ expression. This goes withSi et al. (2015)who observed that TGF- $\beta 1$ may be involved in repair of acute kidney injury and also may promote MSCs homing in vitro by influencing the expression of CXCR4.

The present study showed that mice injected with disintegrin like/domain and mice injected with bothdisintegrin like/domain and BM-MSCs after $\mathrm{CCL}_{4}$ treatment had the highest significant expression of HGF gene compared to all other groups.

The present results were consistent with Ogaly et al.(2015)whoreported that there is decrease in HGF mRNA with $\mathrm{CCL}_{4}$ intoxication. Kim et al. (2005)showed that the anti-fibrotic effect of HGF has been achieved through down-regulation of TGF- $\beta 1$ and inhibition of both the proliferation and activation of HSCs. Zhang et al. (2014)found that HGFcan magnify the effect of adipose tissue122 
derived stem cells (ADSCs) with respect to its anti-apoptotic and antifibrotic properties and the promotion of hepatocyte regeneration. In the present study; the combination of disintegrin like/domain and BMMSCs showed the highest expression of HGF with down-regulation of TGF- $\beta 1$ expression.

Zhao et al. (2012)and Si et al.(2015)confirmed that there is a relationship between the increase of HGF expression and the migration of MSCs. This might indicate that disintegrin/ like domaincould mediate MSCs homing through expression of HGF.

In the present study, histo-pathological examination of liver tissues from the animal groups goes in agreement with studies showing hepatotoxic effect of $\mathrm{CCL}_{4}$ administration made byZaki et al. (2011), Zhao et al. (2012)and Abd EL-Wahab et al. (2014).

Histo-pathological examination of liver tissues from animals injected with $\mathrm{CCL}_{4}$ followed by disintegrin/ like domain or BM-MSCs showed signs of healing and regeneration. Liver sections from animals injected with both disintegrin/ like domain and BM-MSCs after $\mathrm{CCL}_{4}$ showed areas of apparent normal hepatocytes with its hexagonal shape.

Preliminary work was done through tissue culture in which isolated BM-MSCs were treated with disintegrin/ like domain for 48 hours. The cells were examined for gene expression of CXCR4. The experiment showed increase in CXCR4 expression in cultured MSCs withdisintegrin/ like domain compared to untreated control MSCs indicating that disintegrin/ like domain could enhance MSCs homing through SDF-1 $\alpha /$ CXCR4 axis.

\section{CONCLUSION}

This work proofs the reproducibility of disintegrin/ like domain on liver injury and also demonstrated the possible mechanism of stem cell homing to liver injured by $\mathrm{CCl}_{4}$.

\section{ACKNOWLEDGMENT}

This work was supported by Ain Shams Faculty of Medicine Grant's office; Grant No: 41.The authors thank Dr. Eman Kamal Habib; Anatomy Department, Faculty of Medicine - Ain-Shams University, Cairo, Egypt and Dr. Azza Mohammed Hassan;Community Enviromental and Occupational Medicine department, Faculty of Medicine - Ain-Shams University, Cairo, Egypt,for their assistance for this study. 
Conflict of interest: the editor of this journal suggested the project and was co-advisor for the project.

\section{REFERENCES}

Abd EL-Wahab, D., Zaki, W. S., Habib, E. K., Basheer, A, R., Farid, T. M., Nasser, H. EL.T. and EL Asmar, M.F. (2014): Effect of Snake Venom Disintegrin like domain on the Homing of Mesenchymal Stem Cells. International Journal of Stem Cell Research and Transplantation: 02(03): 69-77.

Abdel Aziz, M.T., EL Asmar, M.F. and Atta, H.M. (2011): Efficacy of Mesenchymal Stem Cells in Suppression of Hepato-carcinorigenesis in Rats: Possible Role of Wnt Signaling. J Exp Clin Canc Res. 30:49.

Achliya, G.S., Kotagale, N.R., Wadodkar, S.G .and Dorle, A.K. (2003): Hepato-protective activity of Panchagavya Ghrita against carbon tetra chloride induced hepatotoxcity in rats. Indian journal of pharmacology. 35: 308-311.

Ahmed, S.K., Mohammed, S.A., Khalaf, G. and Fikry, H. (2014): Role of Bone Marrow Mesenchymal Stem Cells in the Treatment of CCL 4 Induced Liver Fibrosis in Albino Rats: A Histological and Immunohistochemical Study. International journal of stem cells.7 (2), pp.87-97.

Amiryan, S. (2011): Antitumor Activity of Disintegrin-Like Components from the Venom of Montivipera raddei. Journal of Cancer Therapy 2 (5): 752-759.

Bergmeyer, H.U., Horder, M. and Rej, R. (1985): Approved recommendation on IFCC methods for the measurement of catalytic concentration of enzymes. Part 2. IFCC method for aspartate aminotransferase. J Clin Chem Clin Biochem. 24: 497-510.

Chapel, A., Bertho, J.M., Bensidhoum, M., Fouillard, L., Young, R.G., Frick, J., Demarquay, C., Cuvelier, F., Mathieu, E., Trompier, F., Dudoignon, N., Germain, C., Mazurier, C., Aigueperse, J., Borneman, J., Gorin, N.C., Gourmelon, P. and Thierry, D. (2003): Mesenchymal stem cells home to injured tissues when co-infused with hematopoietic cells to treat a radiation-induced multi-organ failure syndrome. J Gene Med.5:1028-1038.

De Becker, A. and Van Riet, I. (2015): Mesenchymal Stromal Cell Therapy in Hematology: From Laboratory to Clinic and Back Again. Stem Cells Dev. 24:1713-1729. 
Eom, Y.W., Shim, K.Y. and Baik, S.K. (2015): Mesenchymal stem cell therapy for liver fibrosis. The Korean Journal of Internal Medicine. 30: 580.

Fan, X., Zhang, Q., Li, S., Lv, Y., Su, H., Jiang, H. and Hao, Z. (2013): Attenuation of CCl4-Induced Hepatic Fibrosis in Mice by Vaccinating against TGF- $\beta 1$. PLoS One. 8(12): e82190.

Friedenstein, A.J., Chailakhyan, R.K., Latsinik, N.V., Panasyuk, A.F. and Keiliss-Borok, I.V.(1974): Stromal cells responsible for transferring the microenvironment of the hemopoietic tissues. Cloning in vitro and retransplantation in vivo. Transplantation. 17:331-340.

Hahn, J.Y., Cho, H.J., Kang, H.J., Kim, T.S., Kim , M.H, Chung, J.H., Bae, J.W., Oh, B.H., Park, Y.B. and Kim, H.S. (2008): Pre-Treatment of Mesenchymal Stem Cells With a Combination of Growth Factors Enhances Gap Junction Formation, Cytoprotective Effect on Cardiomyocytes, and Therapeutic Efficacy for Myocardial Infarction. Journal of the American College of Cardiology .51:933-943.

Joanna, F.H., David, W.B., Angela, B.K. and Claire, H.F. (2015): Type, Duration, and Incidence of Pathologic Findings after Retroorbital Bleeding of Mice by Experienced and Novice Personnel. Journal of the American Association for Laboratory Animal Science. 54: 317-327.

Kholodenko, I.V., Konieva, A.A., Kholodenko,R.V., Konstantin, N. and Yarygin, K.N. (2013): Molecular mechanisms of migration and homing of intravenously transplanted mesenchymal stem cells. Journal of Regenerative Medicine and Tissue Engineering. 2:4.

Kim, W.H., Matsumoto, K., Bessho, K. and Nakamura, T. (2005): Growth inhibition and apoptosis in liver myofibroblasts promoted by hepatocyte growth factor leads to resolution from liver cirrhosis. Am J Pathol. 166:1017-1028.

Lee, G-H., Lee, H-Y., Choi, M-K., Chung, H-W., Kim, S-W. and Chae, H-J. (2017): Protective effect of Curcuma longa L. extract on CCl4induced acute hepatic stress. BMC Research Notes.10. 77.

Liepelt, A. and Tacke, F. (2016): Stromal cell-derived factor-1 (SDF-1) as a target in liver diseases. Am J Physiol Gastrointest Liver Physiol. 311:G203-9.

Linard, C., Busson, E., Holler, V., Strup-Perrot, C., Lacave-Lapalun, J., Ihomme, B., Prat, M., Devauchelle, P., Sabourin, J., Simon, J., Bonneau, M., Iataillade, J. and Benderitter, M. (2013): Repeated autologous bone 
marrow-derived mesenchymal stem cell injections improve radiationinduced proctitis in pigs. Stem Cells Translational Medicine.2: 916-927. Ling, K.X., Peng, L., Feng, Z.J., Wei, C., Yan, Y.W., Nan, S., Qi, G.C. and Wei, W.Z. (2016): Stromal Derived Factor-1/CXCR4 Axis Involved in Bone Marrow Mesenchymal Stem Cells Recruitment to Injured Liver. Stem Cells International. 2016: 10 pages.

Livak, K.J. and Schmittgen, T.D. (2001): Analysis of relative gene expression data using real-time quantitative PCR and the $2 \Delta \Delta$ (CT) Method. Methods. 25: 402-408.

Motawi, T.M., Atta, H.M., Sadik, N.A. and Azzam, M. (2014): The Therapeutic Effects of Bone Marrow-Derived Mesenchymal Stem Cells and Simvastatin in a Rat Model of Liver Fibrosis. Cell Biochem Biophys.68: 111.

Nasef, A., Zhang, Y.Z., Mazurier, C., Bouchet, S., Bensidhoum, M., Francois, S., Gorin, N.C., Lopez, M., Thierry, D., Fouillard, L. and Chapel, A. (2009): Selected Stro-1-enriched bone marrow stromal cells display a major suppressive effect on lymphocyte proliferation. Int J Lab Hematol. 31: 9-19.

Ogaly, H.A., Eltablawy, N.A., El-Behairy, A.M., El-Hindi, H. and AbdElsalam, R.M. (2015): Hepatocyte Growth Factor Mediates the Antifibrogenic Action of Ocimum bacilicum Essential Oil against CCl4Induced Liver Fibrosis in Rats. Molecules. 20: 13518-13535.

Otto, P., Kephart, D. and Bitner, R. (1998): Separate isolation of genomic DNA and total RNA from single samples using the SV Total Isolation System. Promega Notes. 69:19-23.

Park, M., Kim, Y-H., Woo, S-Y., Lee, H.J., Yu, Y., Kim, H.S., Park, Y.S., Jo, I., Park, J-W., Jung, S-C., Lee, H., Jeong, B. and Ryu, K-H. (2015): Tonsil-derived Mesenchymal Stem Cells Ameliorate CCl4induced Liver Fibrosis in Mice via Autophagy Activation. Scientific Reports.5 (8616).

Sahreen, S., Khan, M.R., Khan, R.A. and Alkreathy, H.M. (2015): Protective effects of Carissa opaca fruits against $\mathrm{CCl}$-induced oxidative kidney lipid peroxidation and trauma in rat. Journal Food \& Nutrition Research.59 (1).

Shao, C.H., Chen, S.L., Dong, T.F., Chai, H., Yu, Y., Deng, L., Wang, Y. and Cheng, F. (2014): Transplantation of bone marrow-derived mesenchymal stem cells after regional hepatic irradiation ameliorates thio-acetamide-induced liver fibrosis in rats. J Surg Res. 186:408-416. 
Si, X., Liu, X., Li, J. and Wu, X. (2015): transforming growth factor- $\beta 1$ promotes homing of bone marrow mesenchymal stem cells in renal ischemia-reperfusion injury. Int J Clin Exp Pathol.8: 12368-12378.

Sohni, A. and Verfaillie, C.M. (2013): Mesenchymal Stem Cells Migration Homing and Tracking. Stem Cells International. 2013:8.

Takeda, S., Takeya, H. and Iwanaga, S. (2012): Snake venom metalloproteinases: Structure, function and relevance to the mammalian ADAM / ADAMTS family proteins. Biochimica et Biophysica Acta. 1824: 164-176.

Thenappan, A., Li, Y., Kitisin, K., Rashid, A., Shetty, K., Johnson, L. and Mishra, L. (2010): Role of transforming growth factor beta signaling and expansion of progenitor cells in regenerating liver. Hepatology.51:13731382.

Thenappan, A., Shukla, V., Khalek , F.J., Li, Y., Shetty, K., Liu, P., Johnson, R.L., Johnson, L. and Mishra, L. (2011): Loss of transforming growth factor $\beta$ adaptor protein $\beta-2$ spectrin leads to delayed liver regeneration in mice. Hepatology.53:1641-1650.

Wang, C., Fei, Y., Xu, C., Zhao, Y. and Pan, Y. (2015): Bone marrow mesenchymal stem cells ameliorate neurological deficits and blood-brain barrier dysfunction after intracerebral hemorrhage in spontaneously hypertensive rats. Int J Clin Exp Pathol.8:4715-4724.

Weiskirchen, R. (2015): Hepatoprotective and Anti-fibrotic Agents: It's Time to Take the Next Step. Frontiers in Pharmacology.6: 303.

Zaki, W., Nasser, H. and El-Asmer, M. F. (2011): Natural therapeutic agent derived from snake venom. Lambert academic publishing; Electronic publishing.

Zhang, J., Zhou, S., Zhou, Y., Feng, F., Wang, Q., Zhu, X., Ai, H., Huang, X. and Zhang, X. (2014): Hepatocyte Growth Factor GeneModified Adipose-Derived Mesenchymal Stem Cells Ameliorate Radiation Induced Liver Damage in a Rat Model. PLoS ONE. 9: e114670.

Zhao, W., Li, J-J., Cao, D-Y., Li, X., Zhang, L-Y., He, Y. and Dou, K-F. (2012): Intravenous injection of mesenchymal stem cells is effective in treating liver fibrosis. World Journal of Gastroenterology : WJG.18: 1048 -1058 .

Zwillinger, D. and Kokoska, S. (2000): CRC Standard Probability and Statistics Tables and Formulae, CRC Press. ISBN 1-58488-059-7 page 18. 


$$
\text { الملخص العربي }
$$

آلية عمل شبيه الايسنتجرين في هجرة الخلايا الجذعية في أنسجة الكبد المصابة لفئران التجارب الخلابا

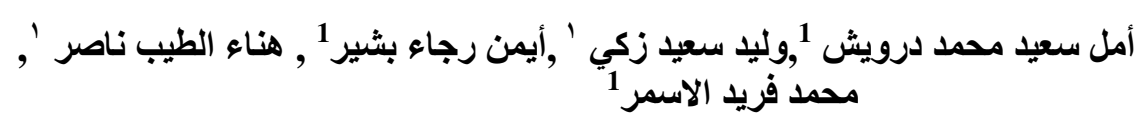

قسم الكيمياء الحيوية الطبية والبيولوجيا الجزيئية, كلية الطب- جامعة عين شمس1

نظر الانتشار حالات قصور في وظائف الكبد لدرجة الفشل الكبدي اصبح الحاجة الى ابتكار

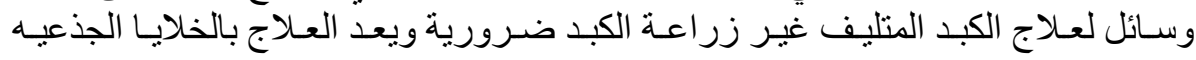
المستخرجة من نخاع العظام و احده من افضل الطرق لتجديد خلايا الكبد المتليفة. شملت هذه

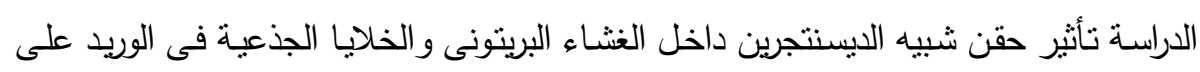
انتاج بعض الجينات فى نسيج الكبد بعد حقن رابع كلوريد الكربون داخل الغشاء البريتونى للفئران

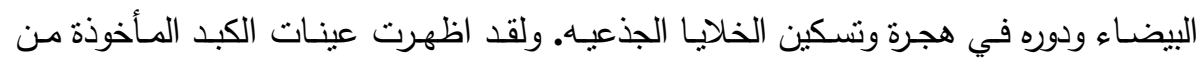

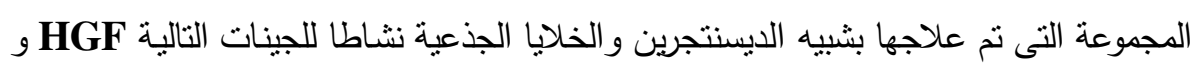

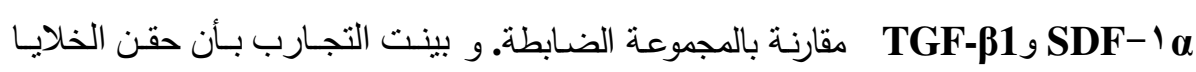

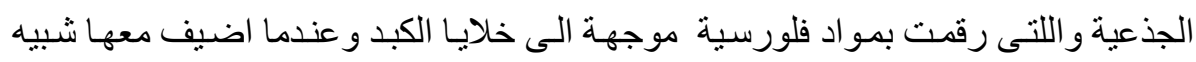

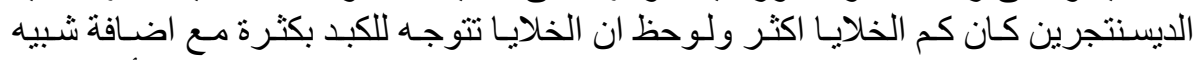

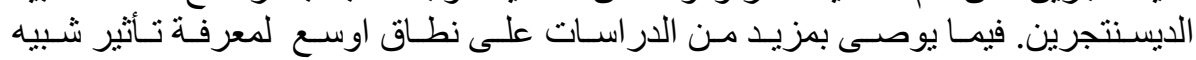
الديسنتجرين في هجرةو تسكين الخلايا الجذعية. 